\title{
Caring Beyond National Borders: The YMCA and Chinese Laborers in World War I Europe ${ }^{1}$
}

\author{
Peter Chen-main Wang
}

$\mathrm{I}$ т is well known that 175,000 Chinese laborers worked for Allied troops in Europe during World War I. ${ }^{2}$ This phenomenon has been recorded in major WWI histories and has become the topic of monographs in Chinese and Western languages. ${ }^{3}$ Chinese laborers solved the Allied problem of a serious manpower shortage and made contributions to military fieldwork, construction, and factory work. ${ }^{4}$ Comparatively speaking, few scholars have

\footnotetext{
${ }^{1}$ The author would like to take this opportunity to thank the Hoover Institution for its grant and for visiting researcher status, which allowed him to conduct this research at the Hoover Institution at Stanford University.

${ }^{2}$ There is no way to know the exact figure of Chinese laborers in Europe, or in France. Different sources give a range between 135,000 and 200,000. G. H. Cole, a major contemporary YMCA worker in France, said the Chinese laborers in France totaled about 140,000: G. H. Cole, "With the Chinese in France," 12 (n.d., preserved at The Kautz Family YMCA Archives of the United States, Minneapolis, Minn., hereafter YMCA Archives of the USA). Chen Ta suggests the number of 150,000 (100,000 for the British, 40,000 for the French, and 10,000 for the Americans): Chen Ta, Chinese Migrations, with Special Reference to Labor Conditions (Washington, D.C.: Government Printing Office, 1923), 143-144. Thomas LaFargue thought there were 150,000 Chinese laborers with the British and gave the total number of the Chinese laborers as 200,000: Thomas LaFargue, China and the World War (Stanford, Calif.: Stanford University Press, 1937), 151. Professor Chen San-ching thinks there were about 175,000: see Chen San-ching, "Jidujiao Qingnianhui yu Ouzhan huagong” (YMCA and Chinese Laborers in Europe in WWI), Bulletin of the Institute of Modern History 17a (June 1988): 55. A more recent study says there were 135,000 Chinese workers in France: Paul J. Bailey, Reform the People: Changing Attitudes Towards Popular Education in Early Twentieth-Century China (Vancouver: University of British Columbia Press, 1990), 234.

${ }^{3}$ The best Chinese work on this topic is Chen San-ching, Huagong yu Ouzhan (The Chinese Labor Force in the First World War) (Taipei: Institute of Modern History, Academia Sinica, 1986), while the leading work in English is Michael Summerskill, China on the Western Front: Britain's Chinese Work Force in the First World War (London: Michael Summerskill, 1982). Nicholas John Griffin deals with British use of the Chinese laborers in his dissertation, "The Use of Chinese Labor by the British Army, 1916-1920" (Ph.D. diss., University of Oklahoma, 1973). It seems the earliest academic work on this topic is Judith Blick's article "The Chinese Labor Corps in World War I," Papers on China 9 (1955): 111-145.

${ }^{4}$ In addition to the Chinese, there were other foreign laborers in France, such as Indians, Spaniards, Portuguese, and Indochinese. One scholar argues that, in terms of quantity and wage, the Chinese were the most ideal for the Allied forces: Nicholas J. Griffin, "Britain's Chinese Labor Corps in World War I," Military Affairs 40:3 (October 1976): 104.
}

Peter Chen-main Wang is a professor at the Graduate Institute of History at National Central University, Taiwan. 
paid attention to the Christian work among the Chinese laborers, which gave them considerable comfort and assistance and which laid the foundation for other service to Chinese laborers in France. ${ }^{5}$ Though some people have a general understanding that the Young Men's Christian Association (including the British YMCA and the International Committee of the YMCA in North America) was the most active and energetic group in offering assistance to the Chinese laborers, little has been written that explains the YMCA operations among the laborers, preventing a fair and thorough evaluation of the YMCA's service to the Chinese laborers. This paper, based on material from the American YMCA Archives, the Canadian Church Archives, and some Chinese writings on this topic, attempts to investigate the origin, operation, and development of this YMCA international project and to assess its significance in church history and in modern China.

Although this paper will focus on the YMCA in China, it is important to note that the $\mathrm{Y}$ was an internationalist organization that pioneered in the employment of indigenous personnel all over the world. The YMCA was ahead of denominational mission agencies on that score, and its commitment to multiculturalism is an important backdrop to this paper. This is an important point, for when the call went out to the YMCA in China to support the movement, there were already Chinese YMCA leaders in place who responded to the call. The YMCA worked incredibly hard, through its agents like Sherwood Eddy, Fletcher Brockman, and others, to cultivate local leaders. The internationalist matrix was already being established by the $\mathrm{Y}$, not only in China but in India and elsewhere.

\section{The Background of Christian Service TO THE ChINESE LABORERS}

Christian involvement in the Allied warfare effort, in fact, was not initiated by the churches. It came from the other direction. The British government, from the beginning, employed a very delicate scheme to manipulate the churches and missionaries for its purpose. As early as 1916, when the British government faced a great manpower shortage and began to contemplate how

\footnotetext{
${ }^{5}$ Chen San-ching wrote a follow-up article after completing Huagong yu Ouzhan that deals with the YMCA service in the Chinese Labor Corps. Chen San-ching, "Jidujiao Qingnianhui yu Ouzhan huagong" (YMCA and Chinese Laborers in Europe in WWI), 53-70. Nicholas John Griffin also wrote an article dealing with Christian efforts for the Chinese laborers: "Chinese Labor and British Christian Missionaries in France, 1917-1919," Journal of Church and State 20:2 (Spring 1978): 287-304. A Canadian scholar approaches this issue from Canadian sources: Margo S. Gewurtz, "For God or for King: Canadian Missionaries and the Chinese Labour Corps in World War I," in China Insight: Selected Papers from the Canadian Asian Studies Association Annual Conference Proceedings, 1982-1984, ed. Min-sun Chen and Lawrence N. Shyu (Ottawa: Canadian Asian Studies Association, Carleton University, 1985), 31-55.
} 
to get laborers from China, the military suggested that British missionaries in China could lend a hand in this matter. In addition to recruiting Chinese laborers, the missionaries were also employed to pacify the Chinese laborers in Europe.

The British military leadership proved correct in utilizing missionary assistance in China. Unlike in the late nineteenth century, missionaries enjoyed a respectable status in early twentieth-century China. ${ }^{6}$ The Chinese, in turn, would not cast any doubt on causes advocated by the missionaries. This was especially true of the British Baptists who carried out Christian work and "won a degree of respect and even of affection among the people of Shantung [Shandong], Shanhsi [Shanxi], and Shensi [Shaanxi] provinces." These particular provinces produced strong-bodied man capable of performing hard work. Therefore, the Baptists, together with other denominations, were, in the eyes of the British military, in a good position to assist the British government in the raising of the Chinese Labor Corps. ${ }^{8}$ In December 1916, the British Legation in Peking issued a formal and urgent call to British missionaries of military age in North China to join the task of creating battalions of the Chinese Labor Corps. ${ }^{9}$

To avoid any backlash over this matter, the military carefully screened out those missionaries deemed politically too liberal, progressive, or pacifist. Then, the British legation persuaded fifteen or so missionaries to accept this task and assured them that "what was requested them was compatible with their sacred calling.... Their work would aid the Allied war effort and would in addition redound to the credit of themselves and the faith that they served." ${ }^{10}$ By January 1917, John Jordan, the British minister in Peking, reported to London that "we have recently started recruiting propaganda through the medium of local British Missionaries."11 This project was successful. According to a modern scholar specializing in Baptist history,

\footnotetext{
${ }^{6}$ The first two decades of the twentieth century were generally recognized as the "golden decades" in church history in China because the old adverse Chinese context had changed tremendously after the Boxer Rebellion. All previous anti-Christian sentiments quickly declined. Not only did the officials and gentry not dare to launch attacks on the churches, but also Confucianism, the very foundation of the Chinese traditional ideology, was put aside when the civil service examination was abolished in 1903. In the eyes of the Chinese youth, Christianity, together with western science and technology, became a source of wealth and power and suddenly was quite popular in China.

${ }^{7}$ Griffin, "The Use of Chinese Labor by the British Army, 1916-1920," 206.

${ }^{8}$ Colonel Charles Robertson, a military attaché attached to the British legation in Peking who played a significant role in the raising of the Chinese Labor Corps, communicated with his colleagues about this matter in December 1916: Griffin, "Chinese Labor and British Christian Missionaries," 290.

${ }^{9}$ Gewurtz, "For God or for King," 32.

${ }^{10}$ Griffin, "Chinese Labor and British Christian Missionaries," 290-291.

${ }^{11}$ Ibid., 291.
} 
of "an estimated seventy thousand Chinese enrolled in Shantung [Shandong] province, many thousands owed their decision to serve the British to the direct influence of local Baptist clergy." ${ }^{\prime 2}$ In addition to serving as propagandists, some missionaries made a further step in helping those Chinese laborers settle into the barracks used for their accommodation in Wei-Hai-Wei, the departing port of Shandong province. ${ }^{13}$ Though there is no way to evaluate the missionary influence on the recruitment of Chinese laborers, church material did reveal that the missionaries made an effort in this matter. ${ }^{14}$

The recruiting and employment of thousands of Chinese laborers, who were mostly illiterate and had never had contact with the outside world, was no easy task for the Allies. ${ }^{15}$ Again, the British military thought about their China missionaries who were able to speak Chinese and were familiar with Chinese customs and culture. The War Office in London was afraid that the missionary presence in the labor corps might have some bad influence, preventing commanders from utilizing the Chinese to the maximum degree. Therefore, the qualifications they set for choosing the missionaries for command positions in the Chinese Labor Corps were "religious orthodoxy and doctrinal dependability, solid Anglo-Saxon cultural background, and desire to participate in the mission of 'civilizing' and controlling the Chinese." $" 16$

The War Office successfully convinced various missionary societies of the compatibility between religious and patriotic duty in assisting in the employment of the Chinese laborers. ${ }^{17}$ However, because of the limited number of missionaries in China and also because of the careful selection of

\footnotetext{
${ }^{12}$ H. R. Williamson, British Baptists in China: 1845-1952 (London: Carey Kingsgate Press, 1957), 100

${ }^{13}$ Griffin, "Britain's Chinese Labor Corps in World War I," 103.

${ }^{14}$ In fact, many sources indicate that Hui-min Company was a major agent in recruiting laborers in China. Professor Chen San-ching gives a good description of the recruiting of Chinese laborers in his book: see Chen, Huagong yu Ouzhan, chapter 2. Based on Western material, Summerskill also gives a picture of their recruitment in China: Summerskill, China on the Western Front, chapters 7-8.

${ }^{15}$ Though "recruitment" is used in this article, the formal usage of the British government is "enrollment." "Recruitment" means "the War Office would have to accept lengthy residual responsibilities and obligations for the welfare of the men and their families," while "enrollment" "implied an element of voluntarism." In this way, the Chinese laborers "were completely at the disposal of the British with little or no hope of any formal recourse to their own government or its representatives." For a detailed discussion of this issue, please see Griffin, "Britain's Chinese Labor Corps in World War I," 103.

${ }^{16}$ Griffin, "The Use of Chinese Labor by the British Army, 1916-1920," 213.

${ }^{17}$ The missionary societies, including the Baptist Missionary Society, the Christian Missionary Society, and the China Inland Mission, did have some reservations about the invitation from the military. However, they gave up their hesitation because the military repeatedly gave them patriotic stimulus, evangelic vision, and assurance that it would offer protection to the Chinese laborers: ibid., 208-211.
} 
the missionaries by the military, the British military accepted very few missionaries for the job as recruiters. Only thirteen former Baptist missionaries were allowed to accompany the Chinese to France as uniformed officers. ${ }^{18}$ As for the most active Christian group involved with the Chinese laborers, the YMCA, the War Office began considering its recreational programs for the Chinese laborers as early as December 1916. However, the field officers, for reasons unknown, initially rejected the voluntary service of the YMCA to the Chinese labor corps. ${ }^{19}$ It is said that the British army command had resisted Chinese-speaking Y secretaries, "fearing that sympathy would dilute discipline." ${ }^{20}$ Some "unofficial" YMCA activities were held for the Chinese labor corps in late 1917, but it took a long while for them to be formally accepted and become a major factor in bringing comfort and stability to the Chinese laborers. The YMCA faced a similar situation in French camps. The French authorities were greatly suspicious of YMCA work and thought the Y people, who might spread ideas of strikes and anarchism, would interfere in their administration of the Chinese laborers. After some negotiation, the French officers allowed some initial development of Y services for Chinese laborers in late November 1917. ${ }^{21}$

\section{Difficulties IN THE EMPloyment of Chinese Laborers in France}

The ideal of a massive Chinese labor force in France was hard to transform into reality. The arrival of more and more Chinese laborers in France early in 1917 soon imposed a tough task on the British and French authorities. It was generally estimated that more than 80 percent of these laborers were illiterate. $^{22}$ In addition to these illiterate farmers, there were also "students,

\footnotetext{
${ }^{18}$ Ibid., 211.

${ }^{19}$ According to a YMCA source, the rejection story goes like this: "As the Chinese were streaming into France early in 1917, a Y.M.C.A. Secretary [James Webster], who had been a Missionary in Manchuria, was standing beside the railway at Etaples one day, when to his astonishment, a trainload of Chinese pulled in and stopped in front of where he was standing. He did not know what dialect they spoke but thought he would try the one he had learned and see if they understood him. To his delight he found they came from the North and that they understood one another perfectly. They had a chat. Soon the train started and the whole crowd waved their hands eagerly to their new found friend. As he stood long looking after the departing train the old love for these people rose in his heart and he longed to do something for the homeless lonely men. In that look of love was born the Chinese Y.M.C.A. in France. On his initiation application was made to the military authorities for permission to do Y.M.C.A. work among the newly arrived Chinese. The reply was a flat refusal": Cole, "With the Chinese in France," 14.

${ }^{20}$ Charles W. Hayford, To the People: James Yen and Village China (New York: Columbia University Press, 1990), 24.

${ }^{21}$ Shi Yixuan, "Faguo liengshi foxin zhi huagong qingnianhui baogao" (Report of the Chinese Labor YMCA in Teysin, Lyons, France), Qingnian jinbu 15 (July 1918): 61.

${ }^{22}$ Cole, "With the Chinese in France," 20.
} 
unemployed minor officials, soldiers, and poverty-stricken lower degreeholders (xiucai). ${ }^{23}$ They knew nothing about Europe and its languages and had not had any opportunity to become familiar with European culture. The tremendous cultural and linguistic barriers between the Chinese laborers and their commanding officers created many misunderstandings that, together with mismanagement and racial attitudes on the part of Allied officers, caused numerous conflicts, strikes, and mutinies among the Chinese labor corps.

The Chinese laborers in France, generally speaking, were organized into different camps under the command of three countries. The British had twenty-three camps located in Northern France, the French eighty-seven camps, and the United States ten camps. When the American Expeditionary Forces came to France, they borrowed 10,000 Chinese from the French. The size of the camps varied. Seven British camps had more than 3,000 men per camp, while many others varied from 100 to $1,000 .^{24}$ The French camps were small in size, varying from 25 to 2,000 , scattered over wider areas. ${ }^{25}$ The "principal" American camps had about 1,500 each. ${ }^{26}$ The Chinese laborers in British camps were divided into companies with 500 each, which were further divided into four platoons and again subdivided into sections. ${ }^{27}$

Since the Chinese were not combatants, they, based on their contracts, were not used close to the Front. Generally speaking, they were "engaged in the handling of military supplies at ports and bases, in repairing roads and building railways, handling munitions, and even digging trenches. After the Armistice, they were sent up to the devastated areas in large numbers where they were engaged in reconstruction and salvage." 28

While the Chinese were provided with food, clothes, lodging, and the agreed salary, the treatment and working conditions varied in each camp, and conflicts occurred not long after their arrival. Basically, the French treated the Chinese

\footnotetext{
${ }^{23}$ Bailey, Reform the People, 234. In other sources, it mentions that many of them had been members of Zhang Xun's army: Summerskill, China on the Western Front, 151, and Dwight W. Edwards, "The Chinese Labourer in France in Relation to the Work of the Young Men's Christian Association. Report to the International Committee of Young Men's Christian Association of North American of Special Mission of Dwight W. Edwards in France April 13May 11th [1918]" (YMCA Archives of the USA), 24. Zhang Xun started an abortive attempt to restore the Manchu dynasty in July 1917.

${ }^{24}$ Chen, Chinese Migrations, 144.

${ }^{25}$ Ibid. According to a report from the French minister of war written in spring 1918, there were "18 places where there are 1000 up of Chinese and 39 places where there are from 100 to 1000 ": Edwards, "The Chinese Labourer in France in Relation to the Work of the Young Men's Christian Association," 19.

${ }^{26}$ Chen, Chinese Migrations, 144.

${ }^{27}$ Blick, "The Chinese Labor Corps in World War I," 117

${ }^{28}$ William Howard Taft, et al., eds., Service with Fighting Men: An Account of the Works of American Young Men's Christian Associations in the World War (New York: Association Press, 1924), 2:364.
} 
laborers in a democratic and sympathetic manner and did not subject the Chinese to strict military discipline. They were allowed to move around locally after working hours or on holidays and to travel to other cities once they obtained a pass. They were not required to march when they went to work but walked informally to the factories. According to a modern researcher, the Chinese "had an easier relationship with their French employers, who were less troubled by the difference between races.",29

This is in contrast to the British camps, where the laborers were a part of the military organization and were subjected to military discipline. Naturally the Chinese resented the limitations imposed on them. ${ }^{30}$ Even after working hours, the Chinese had to stay in the camps. Only one-tenth of them could leave at a time. They could only move within three miles of the camp. ${ }^{31} \mathrm{~A}$ YMCA secretary once said, "Except in the devastated area the men were kept in barbed wire enclosures, much like prisoners of war, and were allowed into the French villages only on special passes and for good conduct." 32 This YMCA worker regretted the confined living of the Chinese laborers, as "it was almost criminal to keep 500 strong healthy men in an enclosure week after week with nothing to do in leisure time but twiddle their thumbs. Of course they would get into mischief."33

Some of the British officers felt no sympathy toward the Chinese. An American YMCA secretary described a British camp with 1,000 Chinese laborers in his report:

The other side thrust upon them is that of the treatment by the noncommissioned officers who supervise their work as a rule. They understand no Chinese language and as little of the Oriental nature. The consequence is that they are too much the slave driver, who cursing and maligning, forces them to their work. ${ }^{34}$

According to another observer, the Chinese laborers were seen "marching daily to work at the vehicle repair shops in Rouen." 35 The officers seldom associated with laborers and revealed only racial contempt for the Chinese. ${ }^{36}$ According to a British officer, he and the other officers "vied with each other for the greatest number of canes broken on backs, legs, shins, and heads. Humiliation,

\footnotetext{
${ }^{29}$ Summerskill, China on the Western Front, 151.

${ }^{30}$ R. M. Hersey, "General Statement Regarding the Y.M.C.A. Work for the Chinese Laborers in France" (March 1919), 7 (YMCA Archives of the USA).

${ }^{31}$ Chen, Huagong yu Ouzhan, 122.

${ }^{32}$ Cole, "With the Chinese in France," 12.

${ }^{33}$ Ibid., 19.

${ }^{34}$ Edwards, "The Chinese Labourer in France in Relation to the Work of the Young Men's Christian Association," 19.

${ }^{35}$ Summerskill, China on the Western Front, 150.

${ }^{36}$ Chen, Huagong yu Ouzhan, 123.
} 
however, was found to be the most effective type of punishment, and it was used liberally." ${ }^{37}$ A YMCA volunteer, T. F. Tsiang (Jiang Tingfu), observed that "the French officers were much less race conscious. They were more democratic in their manners and took a more paternalistic interest in their laborers. The British stood on their dignity as officers, and perhaps as white men, most of the time." ${ }^{\prime 38}$

Under these circumstances, conflicts and disturbances occurred from time to time in the Chinese labor camps, especially in the British battalions. One source indicates that "from 1916 through 1918 twenty-five disturbances were recorded by the Chinese labor commissioners, including four riots, seven strikes, two fights among laborers, three violations of company rules, and two cases of "conspiracy against the company." "39 The consequences of these conflicts were tragic. It is reported that "between June 1917 and June 1918 , ten Chinese workers were executed for infractions of discipline." ${ }^{, 40}$ More were fined and imprisoned. Quite a few sources talk about the frequent occurrence of disturbances. For example, "Before the YMCA arrived on the scene, there were riots and strikes almost every few days; many of these were simply the result of language difficulties and misunderstandings on both sides." ${ }^{\prime 1}$

A few examples of the disturbances will help us better understand the language and cultural barriers. The most famous occurred when a British officer shouted to his labor force "Let's go" when he wanted the laborers to move. The Chinese did not understand English, and the word "go" sounds like "dog" in Chinese. The result was that all the Chinese refused to work that day. ${ }^{42}$ Another strike occurred when the Chinese laborers were fed horse meat. $^{43}$

In a similar circumstance, "when one company was moved to a new locality, it happened that after a long march through the mud and rain they came to their destination only to learn that the commissariat had not arrived and that no provision had been made for their food or camp. It was too much for the men and they rebelled, running in every direction, completely disbanding., ${ }^{44}$ A further example is related to Chinese cultural custom:

\footnotetext{
${ }^{37}$ Blick, "The Chinese Labor Corps in World War I," 124-125.

${ }^{38}$ Chen, Chinese Migrations, 147.

${ }^{39}$ Blick, "The Chinese Labor Corps in World War I," 128-129.

${ }^{40}$ Hayford, To the People, 24.

${ }^{41}$ Blick, "The Chinese Labor Corps in World War I," 128.

${ }^{42}$ R. M. Hersey, "Annual Report Letter, R. M. Hersey to the International Committee of the Young Men's Christian Association of North America," received 14 November 1919, p. C1 (YMCA Archives of the USA).

${ }^{43}$ Blick, "The Chinese Labor Corps in World War I," 129.

${ }^{44}$ R. M. Hersey, “Annual Report Letter,” 8.
} 
In one company, one of the officers knew a little Chinese and was greatly appreciated by the men [Chinese laborers]. The men grew fond of him and when the announcement was made that he was to be transferred to another center, they decided to accompany him to the station. It happened that he left early in the morning, but in their desire to show a proper Chinese spirit they were mustered out before daylight on the parade ground.... [The] major in charge ordered the men to return to their headquarters. The rudeness of the command was greatly resented by the men, all of whom went on strike. ${ }^{45}$

According to Chinese custom, when a friend bids farewell the host should "song" him (see him off). Since the Chinese laborers treasured their friendship with the departing officer, they got up early to see him off at the hour of his departure. They did not mean to act contrary to rules, and they were deeply offended by the rough and inconsiderate treatment they received. ${ }^{46}$

Hard, boring, and long work, confinement inside the barbed wire of the camps, and the lack of recreational facilities in the camps led the laborers to seek entertainment through various vices. Gambling, according to several sources, was considered the most serious vice among the Chinese laborers. The gambling was so rampant that a great number of laborers lost their salaries in one or two days after payday. ${ }^{47}$ Some who lost their money turned to violence. ${ }^{48}$ Some who were in debt would try to escape from their creditors by submitting themselves to the authorities, expecting to be transferred somewhere else to work. ${ }^{49}$ Another prominent vice among the Chinese laborers was prostitution. Many of them visited local brothels and contracted venereal diseases. ${ }^{50}$ When five hundred Chinese laborers were relocated to another area, some French prostitutes moved along with them. ${ }^{51}$ Laborers also engaged in excessive drinking, fighting, burglary, and rape. ${ }^{52}$

${ }^{45}$ Ibid., 6-7.

${ }^{46}$ Cole, "With the Chinese in France," 15.

${ }^{47}$ According to the testimony of a Chinese interpreter, "About 15,000 francs are paid each month to the men of our company. In two days 10,000 francs are in the hands of a half dozen men. In one day more at least 8,000 francs are in the pocket of one man": Paul Patton Faris, "Friends for the Chinese in France," The Continent 49:45 (November 7, 1918): 1261.

${ }^{48}$ Cole, "With the Chinese in France," 17-18.

${ }^{49}$ I. H. Si, "With the Chinese Laborers 'Somewhere' in France," The Chinese Students' Monthly 13:8 (June 1918): 449.

${ }^{50} \mathrm{~A}$ source indicates that at least $20 \%$ were doctoring themselves for venereal disease: Blick, "The Chinese Labor Corps in World War I," 122. According to a letter from the Royal Army Corps, the second major problem was homosexuality: Gewurtz, "For God or for King," 41.

${ }^{51}$ Edwards, "The Chinese Labourer in France in Relation to the Work of the Young Men's Christian Association," 4.

${ }^{52}$ Chen San-ching has listed a number of vices among the Chinese laborers: see Chen, Huagong yu Ouzhan, 136-139. 
The British officers recognized the roots of the problem and, in fact, clearly knew what should be done to remedy the situation. Lieutenant-Colonel Bryan Fairfax, the British officer in command of the Chinese Labor Corps,

set out 20 causes which he regarded as contributing to the unrest. ... Eight of these concerned the quality of those administering the Chinese Labour Corps. He felt that there had been insufficient recognition of the need for 'specialist human machinery'; by this he meant people who could move easily among the Chinese, listening to their grievances and explaining to them what work was required, and how it should be accomplished. ${ }^{53}$

However, these requirements were too high to be reached by the British officers themselves. Up to May 1918, there were about fifty or sixty missionaries working among the Chinese laborer battalions of $100,000 .^{54}$ At this time, the British authorities had to appeal again for the assistance of Christian organizations.

\section{The YMCA Service Goes Beyond National Boundaries}

By 1918, the Chinese laborers had become a serious headache for the British military instead of a major labor force for the Allied cause. The morale of the Chinese labor battalions, it was said, was so low that it had reached a crisis point. According to a Canadian reporter, "in a short time the Chinese Labor Corps as a whole was not working up to much more than fifty percent of efficiency." 55 At this time, the British National Council of the YMCA opened work in thirty centers, though it had not received formal permission. ${ }^{56}$ Its excellent performance in adjusting disputes and strikes and in raising the morale of the Chinese laborers attracted attention from the military authorities.

The British military leaders finally made up their minds to let Christian people take over the matter of raising the morale of the Chinese laborers. On February 12, 1918, the adjutant general, Sir Nevil Macready, sent the British National Council of the YMCA a letter asking them to take sole responsibility for "entertainment, recreation and canteen work for the Chinese Labour Corps with the British Expeditionary Force." ${ }^{, 57}$ Of course,

\footnotetext{
${ }^{53}$ Summerskill, China on the Western Front, 154.

${ }^{54}$ Edwards, "The Chinese Labourer in France in Relation to the Work of the Young Men's Christian Association," 4.

${ }^{55}$ O. D. Austin, "From Far Cathay and Back Again," Canadian Herald, November 1919, 110.

${ }^{56}$ Taft, Service with Fighting Men, 2:365.

${ }^{57}$ A. Philip Jones, Britain's Search for Chinese Cooperation in the First World War (New York: Garland, 1986), 188. For the related information on the church side, please see United Church of Canada/Victoria University Archives, Board of Foreign Missions, Presbyterian Church in Canada, Chinese Labor Corps in France. 79.201C-File 1, 1917. "Statement in regard to Y.M.C.A. Work for Chinese in France."
} 
this work was beyond the ability of any single Christian organization or denomination. The British YMCA did not let this opportunity slip away. They on the one hand accepted this assignment from the government and on the other appealed to their Christian brothers domestically and internationally.

On March 14, 1918, the British YMCA invited 11 missionary societies to meet to discuss the call from the government. ${ }^{58}$ They reached two unanimous resolutions that developed into the involvement of the International Committee of the YMCA in North America in this project and later significantly changed the life and morale of the Chinese laborers in France. The first resolution was "that the British Missionary Societies be invited to provide 40 missionaries as their quota for carrying on this work, recalling men from China if necessary.",59 With the second resolution, they also appealed to their religious brothers in North America "to secure the cooperation of Canadian and American Missionary Societies to take an equal share with the British Societies in this all important task." 60 Based on the second resolution, Dr. Ritson, chairman of the Standing Committee of the Conference of British Missionary Societies, sent a dispatch two days later to Dr. James Barton, Chairman of the Committee of Counsel and Reference of Mission Boards of America. Ritson informed their American brothers about these two resolutions:

Meeting representing eleven British Missionary Societies unanimously resolve British should provide forty missionaries for Y.M.C.A. to work among Chinese in France. This will necessitate recalling missionaries from China. We also decided to request you to arrange that vernacularspeaking missionaries shall be available for this urgent unique opportunity. ${ }^{61}$

\footnotetext{
${ }^{58}$ The societies who sent representatives to the meeting were the British and Foreign Bible Society, the Religious Tract Society, the China Inland Mission, the Baptist Missionary Society, the English Presbyterian Mission, the Wesleyan Methodist Missionary Society, the Primitive Methodist Missionary Society, the Church Missionary Society, the London Missionary Society, the Fellowship for Christian Service, VMMS, and YMCA. Besides these, representatives of the Society for the Propagation of the Gospel in Foreign Parts and the Ny Fiangonana Frenjy Malagasy (FFMA) had been consulted, and they were in agreement with the decision of the meeting: United Church of Canada/Victoria University Archives, Board of Foreign Missions, Presbyterian Church in Canada, Chinese Labor Corps in France. 79.201C-File 1, 1917. Dr. Ritsen to Dr. Barton, 18 March 1918.

${ }^{59}$ The proviso with this resolution was that those missionary societies that attended the meeting might not use the same 40 the whole time, but they "shall use men who have returned from the China field or who happen to be on furlough and make up the number with men specially drawn from the field for varying periods": ibid.

${ }^{60}$ Ibid.

${ }^{61}$ United Church of Canada/Victoria University Archives, Board of Foreign Missions, Presbyterian Church in Canada, Chinese Labor Corps in France. 79.201C-File 1, 1917. James L. Barton to Dear Brethren, 26 March 1918.
} 
Upon receiving this dispatch, Barton first consulted with the International Committee of the YMCA and obtained its agreement to take charge of this matter. Though it is not clear why Barton would contact that group first, there are two possible reasons for doing so. First, he acted in accordance with the British cable about applying "Y.M.C.A. work" to the Chinese laborers in France. (Though the YMCA was first founded by a British citizen, George Williams, in London, it soon had a faster and greater development in America under the title of the International Committee of the YMCA in North America.) ${ }^{62}$ Second, the International Committee had already undertaken work for the Chinese under French command. ${ }^{63}$ Then, Barton sent an open letter on March 26 to all mission boards of North America to urge all mission boards carrying on work in China to enter into correspondence at once with Edward C. Jenkins of the International Committee. In this way, the International Committee gradually assumed the leading role in giving assistance to the Chinese laborers in France.

At this juncture Dwight W. Edwards, Y secretary of the Peking Association, was sent by the International Committee to France to investigate the field and to start YMCA work for the Chinese laborers. ${ }^{64}$ Edwards stayed in France from April 13 to May 11 and presented the International Committee a thorough report that in turn became the major basis for the development of this project in France. Edwards raised eight compelling reasons for undertaking work among the Chinese laborers. First, the Chinese laborers were suffering socially, physically, and psychologically, and they badly needed YMCA work to improve their conditions; second, the situation presented a great missionary opportunity that was good not only for these laborers but also for Christian development in China in the long run; and third, it was a golden opportunity to provide the Chinese laborers with a favorable impression of the West that would forward the Western civilization among their countrymen. ${ }^{65}$

The YMCA work for the Chinese laborers was seriously understaffed in France. At the time of Edwards's investigation,

27 huts and 13 marquees, or canteens, are being operated, all but two of which are in the L. of C. There is a staff of 18 Chinese-speaking workers,

\footnotetext{
62“"At the beginning of the War, there were over 600 branches in Britain, with 146,000 members, and over 1,900 branches in the U.S.A., with 456,000 members": Summerskill, China on the Western Front, 171-172.

${ }^{63}$ Taft, Service with Fighting Men, 2:365.

${ }^{64}$ Two months before the British invitation, the International Committee had begun to work out sending a secretary to supervise association work for Chinese laborers in France: "Correspondence with New York in regard to Edwards' trip to France" (YMCA Archives of the USA).

${ }^{65}$ Edwards, "The Chinese Labourer in France in Relation to the Work of the Young Men's Christian Association," 2-6.
} 
only one of whom, Major J. H. Wallace, General Supervisor has had any Association experience. Non-Chinese-speaking workers are being temporarily used to meet the emergency. ${ }^{66}$

After carefully going over the situation place by place, Edwards saw the need for 127 new Chinese workers for the project. The British Missionary Societies could supply thirty of them, and the remainder could come from the United States and China. ${ }^{67}$ In regard to the type of Chinese secretaries, Edwards emphasized the following characteristics: 1) sound Christian character; 2) ability to speak any Mandarin dialect and English; 3) tact, or recognizing the necessity of not interfering with military discipline in any way; and 4) experience that would justify belief in their being able to do a good job. ${ }^{68}$

Two important suggestions in the Edwards report are worth attention. The first was unification of the work for Chinese in France. Because YMCA services were conducted among the British, American, and French armies, there were "three distinct branches of service, each independently controlled, organized, financed and staffed." ${ }^{69}$ The second was to get the support from the Chinese Christians - to mobilize a coordinated effort from the Chinese YMCA to link up the work in France with that in China. ${ }^{70}$ Comparatively speaking, the latter issue was more successfully executed and had significant consequences in the future.

The International Committee was enthusiastic about the vision to take care of the Chinese laborers, to implant civil, Western, and Christian influences in those laborers, and to let the laborers become messengers in transmitting their understanding of the West and Christianity to their native people. In order to realize this vision, the committee needed to have a great number of Chinese Christians devote themselves to this project. For this purpose, the International Committee did a great deal to stir up a sense of mission in the Chinese YMCA members to get their full cooperation. This was shown in the frequent exchange of cables and letters between the International Committee and the Chinese YMCA. For example, E. C. Jenkins wrote to C. W. Harvey, the major American secretary in China:

We believe, however, that the situation in France is of great importance to China; otherwise we would not be spending so much time and energy in

\footnotetext{
${ }^{66}$ Ibid., 6.

${ }^{67}$ Ibid., 16

${ }^{68} \mathrm{Ibid}$

${ }^{69}$ Ibid., 20.

${ }^{70}$ Ibid., $21-22$. Edwards even provided a clear suggestion of how to do this by writing: "To help me in this large problem of getting men and supplies and arousing interest and support from the Christian agencies in China, it would be of great help to have strong letters from Dr. Mott to David Yui, C. W. Harvey, and E. C. Lobenstine, urging careful consideration of this need."
} 
attempting to meet the calls for men. ... I do not believe, however, that you men appreciate fully the opportunity before the Association in France. ${ }^{71}$

John R. Mott also urged David Yui (Yu Rizhang), general secretary of the Chinese YMCA, to give full cooperation to this project by saying, "I have discussed all phases of the subject with him [Edwards] and have requested him to lay before you the reasons why we deem it urgently desirable that the Association Movement in China put itself strongly behind this undertaking. I am confident that you and those associated with you will recognize the strategy and providential character of this effort and that you will gladly do all in your power to ensure its highest success. I pledge you my full cooperation in helping to make possible the desired results."

Two American YMCA secretaries toured China to share their experiences in France in order to effectively arouse the interest and enthusiasm of the Chinese people for this project. When Edwards went to Shanghai after his French mission, a special meeting of Executive Committee and national secretaries was called. Edwards "gave a very full account of the conditions among the laborers and the work now being carried on by the Association for them and the plans of the International Committee for extending this work." ${ }^{, 73}$ Another American secretary went to China in late 1918 for the same purpose. Through the arrangement of the International Committee, W. W. Peter, a China Y secretary who would finish his studies at Harvard Medical School in June 1918, would go to France "to deliver health lectures in the Chinese language to the Chinese laborers" and "to carry the facts [as] regards this work back to China and present them in such a way before leaders in that country that it will be able to recruit the number of workers that are being obtained from that country for the Chinese Labor Battalions.,"74

The response to the appeal of the International Committee and to the lectures of the two American secretaries in China was extremely warm. Right after the special meeting in Shanghai, a committee in charge of the "Chinese Labor Division" was formed to enlist secretaries in China for the work in France, with Edwards as executive secretary and Hening as business secretary. ${ }^{75}$ This committee even set a goal of sending 100 men to France as YMCA

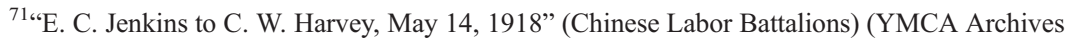
of the USA).

72“"John R. Mott to David Yui, May 18th, 1918” (Chinese Labor Battalions) (YMCA Archives of the USA).

${ }^{73 “ " C h a s . ~ W . ~ H e n i n g ~ t o ~ D r . ~ J o h n ~ R . ~ M o t t, ~ A u g u s t ~ 1, ~ 1918 ” ~(C h i n e s e ~ L a b o r ~ B a t t a l i o n s) ~(Y M C A ~}$ Archives of the USA).

74“"Information Concerning Dr. W. W. Peter, Chinese Labor Battalions [November 1918]" (YMCA Archives of the USA).

${ }^{75}$ Ibid.
} 
secretaries. ${ }^{76}$ Twenty-nine Chinese YMCA secretaries were sent in 1918 and early 1919 to join the Y service to the Chinese laborers in France. ${ }^{77}$ Further evidence of the effective appeal to the Chinese in connection with the Chinese laborers in France was the raising of $\$ 180,000,000$ for the united war work campaign. At the end of the campaign, China's contribution was $\$ 1,360,000 .^{78}$ This was a splendid testimony to China's faith in the YMCA organization.

One requirement for YMCA workers in France was the ability to speak both Mandarin and English. ${ }^{79}$ Initially, the International Committee appealed to Chinese Christian students in the United States. The International Committee did get about forty Chinese students who put their studies on hold and answered the call. Though it was not clear how the International Committee mobilized the Chinese students in the United States to join their service in France, the major organ of the Chinese Students' Organization echoed this invitation in its "Editorials":

These common laborers in France are the messengers of the wider world just as the crusaders once were in the late centuries of the Middle Ages. This leads us to say that when an opportunity comes to us so that we may help to make their stay abroad profitable, it is highly necessary that we give it careful consideration. The International Committee of the Young Men's Christian Association has issued a call for a number of Chinese students to go over to France as secretaries of the Association. We hope our student body will give it the rightful support. ${ }^{80}$

Through the mobilization of the International Committee, there were 109 YMCA secretaries working for the Chinese laborers. According to a report in mid-1919, sixty-one of them were in the British area and thirty-five in the French area. Thirteen had yet to be assigned. ${ }^{81}$ S. J. Chuan, the general secretary of the Christian work among Chinese students in France, reported in mid-July 1919 that there were seventy-four Chinese student secretaries. ${ }^{82}$

\footnotetext{
76،David Z. T. Yui to W. W. Peter, September 7, 1918” (Chinese Labor Battalions) (YMCA Archives of the USA).

${ }^{77}$ Chen Weixin, "ZhuFa Huagong qingnianhui jiyao" (Summary of YMCA Work for the Chinese Laborers in France), Zhonghua Jidu jiaohui nianjian (China Church Year Book), No. 6 (1921), $208-210$.

${ }^{78}$ Young Men's Christian Association with the Chinese Labor Corps in France (Paris: Herbert Clarke, 1919), 10.

${ }^{79}$ It is very interesting to note that many British YMCA workers in the Chinese Labor Battalions were not able to speak Chinese: Summerskill, China on the Western Front, 172.

80“"Editorials," Chinese Students' Monthly 13:16 (April 1918): 301.

${ }^{81}$ Hersey, "General Statement Regarding the Y.M.C.A. Work for the Chinese Laborers in France," (March 1919), 7.

82،'Y.M.C.A. Chinese Section, Report of Conference of Workers held at Peronne on 23/24 July 1919," 31 (YMCA Archives of the USA).
} 
Twenty-nine of them came directly from China, thirty-nine were from the United States, five were from the United Kingdom, and one was a Chinese student studying in France. ${ }^{83}$ Those $109 \mathrm{Y}$ secretaries did tremendous YMCA service that immediately solved many conflict issues, created better understanding with the laborers, and offered basic education to the Chinese laborers. Praise of the Y secretaries' performance was recorded numerous times in various YMCA and Allied documents.

The YMCA work could be divided into three categories: educational, recreational, and religious. The educational function included offering various courses, such as Chinese, English, French, history and geography, and mathematics. Many lectures on public affairs, citizenship, health and hygiene, and the meaning of the world war were designed to help the Chinese laborers when they went back to China. James Y. C. Yen's experimental teaching of the basic Chinese characters proved a great success, and his Chinese Laborers' Weekly was a useful instrument in arousing interest in studying Chinese and in bringing the modern world to these laborers. As for the recreational activities, although many of the Chinese did not care for athletics after ten hours of manual labor each day, some of them enjoyed playing soccer, indoor baseball, basketball, and volleyball while many others played Chinese chess, kite flying, and other games. Amateur theater performances by laborers themselves attracted a great deal of attention from other laborers. As for the religious aspect, these $\mathrm{Y}$ secretaries offered sermons, Sunday services, Bible classes, prayer meetings, and even baptisms. Although some camps were not allowed to hold religious services, the secretaries still tried to offer Christian influence on a personal level. In addition to the above activities, a home letter-writing service offered by the Y secretaries was also deeply appreciated by the laborers. ${ }^{84}$

The unification of the work for the Chinese in France, urged by Edwards, was not so successful. While the International Committee won full support and cooperation from the American area and the French area, they encountered unexpected complications with the British YMCA. When R. M. Hersey was sent by the International Committee to coordinate the $\mathrm{Y}$ work in France, he found that Mr. McCowan, who then took charge of the British work for the Chinese as well as the general work, "has never been enthusiastic about close

\footnotetext{
${ }^{83}$ The number of the Chinese student secretaries was slightly different in various sources. Some said there were over forty from the United States while some said 39 and some 38. Chuan (Quan) said "more than 40": ibid. However, an American source gave a number of 38: Taft, Service with Fighting Men, 2:365. The reason I use the number 39 is because if we are certain that 29 were from China, 5 from the United Kingdom, and 1 from France, the rest of them must number 39.

${ }^{84}$ The Y service for the Chinese laborers can be found in many works, such as Shi Yixuan, "Faguo liengshi foxin zhi huagong qingnianhui baogao," 61-63; Blick, "The Chinese Labor Corps in World War I," 126-128; Summerskill, China on the Western Front, 170-174; Chen, "Jidujiao Qingnianhui yu Ouzhan huagong," 53-70; and many church materials.
} 
cooperation, and has preferred to consider the Chinese work as a British enterprise. ${ }^{, 85}$ Further complicating cooperation were the facts that a British secretary who was asked to keep separate accounts for the Chinese work failed to do his duty and that shipments designed for the Chinese work were used extensively for the British association. ${ }^{86}$ Even when the British Association encountered a great financial difficulty in 1919 and asked the International Committee for a loan of 10,000 pounds to help it over a crisis until the end of the year, Mr. McCowan still turned down having one central office despite the potential for unifying the Chinese Department. ${ }^{87}$ Apparently the representative of the International Committee was a little less confident in the British Association and suggested that his home Committee give "support to the Chinese work in the British area, but that all funds be administered through the International Committee Treasurer." ${ }^{\prime 88}$ While the leader of the British YMCA recalled its wartime service in retrospect, he gave much credit to his own side. For example, in the matter of getting Chinese secretaries from China, he said, "For these Chinese huts we needed Christian men of their language. We communicated with the Y.M.C.A. headquarters in Shanghai, and they sent over a number of Chinese secretaries who proved a very great help." ${ }^{89}$ This account completely ignored the great efforts of the International Committee during this time.

\section{Effects of the YMCA Service to Chinese Laborers}

The YMCA work won much praise from numerous writers and scholars for its service to the Chinese laborers. However, very few people are aware that this international operation strongly influenced the Chinese students in the United States and the Chinese YMCA. This section, mainly based on church material, will investigate to what extent the YMCA service and experience influenced the Chinese students and how the Chinese YMCA responded to the challenges and shaped a new development in China.

As for the Chinese YMCA secretaries, whether from China directly or overseas students, they did not have much previous experience with Chinese laborers. Their services in France became a self-education. For many of them, it was the first time they were associated with foreign missionaries in the field. What they saw with their own eyes about missionary service for

\footnotetext{
${ }^{85}$ Hersey, "General Statement Regarding the Y.M.C.A. Work for the Chinese laborers in France," (March 1919), 5.

${ }^{86}$ Ibid., $5-6$.

${ }^{87}$ Ibid., 6.

${ }^{88}$ Ibid., 14.

${ }^{89}$ Summerskill, China on the Western Front, 172.
} 
their fellow countrymen cleared up many past misunderstandings and left a strong impression on them. For example, a student who was educated at a mission school in China held grudges against the missionaries and the foreign invasion of China in the nineteenth century. When he came to France and worked with the foreign YMCA secretaries, he changed his attitude:

Undoubtedly those experiences here have made me able to sympathise with the missionaries and their work in China. I was against missions and missionary work, but since coming to France that has entirely changed. This experience has made me realise what sacrifice and difficulties all of the missionaries must have undergone to do their work for our fellow countrymen in China. ${ }^{90}$

Through working with foreign YMCA secretaries, some Chinese students found the meaning of life for themselves. A student shared that he came to France not primarily to serve his fellow countrymen, but to try to "find himself." After rendering a year's service in France, he was very happy because "he could say confidently that he had found himself-not through his own ability but through the work that his British and American associates were doing." 91

The Y work of foreign secretaries also stimulated the passion of Chinese students to serve their own countrymen. The first Chinese student secretary in France observed:

What has China done for these men? Aside from placing an attaché in Paris to take charge of the complaints of all the Chinese scattered in more than seventy different places, our Government has done nothing whatsoever in their interests. Neither have any individuals or organizations in China been public-spirited enough to take an interest in the Chinese laborers in France. When we come to think what the United States has done, and is still doing, for her men in France, we ought to be ashamed of ourselves for our indifference toward the welfare of our men here. ${ }^{92}$

Even at the end of his one-year contract, a Chinese student determined to be the last to leave the Chinese work in France "because there are so many Americans and Britishers who are not our fellow countrymen, staying here at Greater sacrifice, for the sake of the welfare of our fellow countrymen, and for that I believe it is my duty to stay in this work until everybody is gone." ${ }^{93}$ In fact, this passion was even shared by many other students who did not

\footnotetext{
90، Y.M.C.A. Chinese Section, Report of Conference of Workers held at Peronne on 23/24 July $1919, " 31$.

${ }^{91}$ Ibid.

${ }^{92} \mathrm{Si}$, "With the Chinese Laborers 'Somewhere' in France," 452.

93،"Y.M.C.A. Chinese Section, Report of Conference of Workers held at Peronne on 23/24 July $1919, " 31$.
} 
come to France. Quite a few articles written by Chinese students in the United States urged their fellow students to pay attention to the future of China and to their own countrymen. ${ }^{94}$

Generally speaking, the Chinese student secretaries recognized the poor condition of the Chinese labor class and the usefulness of the $\mathrm{Y}$ work in France, and they therefore promoted a mass education movement in China. Sixty Chinese student secretaries held a three-day meeting in April 1919 at Versailles to exchange viewpoints and experiences and to contemplate the application of their work to China. One of their resolutions was "to petition the national Committee of China to immediately devise ways and means to project the hut idea in France to China for the uplifting and education of the masses."95 This resolution was further developed into a well-designed memorandum under the title of "The Y.M.C.A. Hut as an Agency of Mass Education in China." "96 The consensus of the student secretaries was that the Chinese masses must be educated and enlightened if China were to move toward democracy, peace, and justice. As James Yen said many years later about what he learned in France, "I discovered the ignorance not of the coolies but of the intellectuals like myself." 97 This awakening of the Chinese students was very significant and greatly influenced the Mass Education movement and also the development of the Chinese YMCA in China.

The service for the Chinese laborers proved an important turning point in the development of the YMCA movement in China. When urgings from the United States arrived at the headquarters in Shanghai, the Chinese YMCA responded warmly. Not only were twenty-nine secretaries sent, but also many materials for recreational and educational purposes were shipped to France. In the fundraising movement that followed, the Chinese $\mathrm{Y}$ also played an important role in contributing fourteen times the assigned goal of $\$ 100,000$ to the united war work campaign. However, none of the above can be compared with the Mass Education Movement that had its origin in labor service in France and became a major project of the Chinese YMCA over the next fifteen years.

The success of teaching Chinese laborers in France, possibly together with the memorandum of the Chinese student secretaries, was very encouraging to the leaders of the Chinese YMCA. David Yui, the general secretary of the Chinese YMCA who received his master's in education at Harvard, wanted to apply the same method in China. Yui long believed that the greatest

\footnotetext{
${ }^{94}$ Most of these articles were published in The Chinese Students' Monthly and The Chinese Students' Christian Journal.

${ }^{95}$ [S. J.] Chuan, "A Brief Report of the Versailles Conference for the Chinese Secretaries of the Chinese Department of the Y.M.C.A. in France," 5 (YMCA Archives of the USA).

${ }^{96}$ I. H. Si, C. H. Wang, and T. F. Tsiang drafted this memo and published it in The Chinese Students' Christian Journal 6:2 (November 1919): 83-85.

${ }^{97}$ This quotation is from Hayford, To the People, 30.
} 
handicap to the progress of the Chinese nation was the illiteracy of the vast majority of China's people. Yu therefore decided to "put the Association's energy and resources behind a mass education experiment." those Chinese secretaries who had worked in Europe, such as James Y. C. Yen and Daniel $\mathrm{Fu}$ (Fu Ruoyo), and he established the section of mass education under the Education Department of the Chinese YMCA. The experimental campaigns were so successful that James Yen was invited to assume the general secretaryship of the National Mass Education Association in 1923. Yet the Chinese YMCA continued to promote the Mass Education Movement and even further expanded it to the Citizenship Education Movement, which gave the knowledge and training of citizenship to the common people. ${ }^{99}$ The Mass Education program of the YMCA was very popular and, in the report of Daniel Fu in 1935, a quarter million people had attended the schools of mass education of the Chinese YMCA. ${ }^{100}$

The International Committee also advised the Chinese YMCA to give follow-up attention to the returned laborers so that they could share their French experience with the people around them. On October 7, 1918, John R. Mott informed David Yui that "it is, therefore, a matter of paramount importance that the home forces must be mobilized as soon as possible in order to be ready to conserve and utilize whatever results the work in France shall yield. Many of the laborers will return to China and all of them will have received some idea at least of the Y.M.C.A."101

Though a general survey of the YMCA service for the returned laborers is still needed, many YMCA letters and reports from various parts of China indicated the Y's immediate attention to the laborers. When the returned laborers began to arrive in China in early March 1919, the Chinese Y assigned Mr. Todnem of the Tsinanfu (Jinanfu) Association to assist the follow-up work in Shandong. ${ }^{102}$ The follow-up activities could be divided

\footnotetext{
${ }^{98}$ Shirley S. Garrett, Social Reformers in Urban China: The Chinese Y.M.C.A., 1895-1926 (Cambridge, Mass.: Harvard University Press, 1970), 157-158.

${ }^{99}$ For a general introduction to the development of the Mass Education Movement and later the Citizenship Education Movement of the Chinese YMCA, see Peter Chen-main Wang, "Yu Rizhang yu kongmin jiaoyu yundong (David Yui and the Citizenship Education Movement)," in Jidujiao yu Zhongguo xiangdaihua guoji xиeshu yantaohui lunwenji, ed. Lin Zhiping (Proceedings of the International Symposium on Christianity and the Modernization of China) (Taipei: Cosmic Light, 1994), 499-530.

${ }^{100} \mathrm{Fu}$ Ruoyu, "Qingnianhui duiyu pingmin jiaoyu zhi gongxian" (The Contributions of the YMCA to Mass Education), in Zhonghua Jidujiao qiannianhui wushi zhounian jiniance (The Memorial Volume of the Fiftieth Anniversary of the Young Men's Christian Association of China) (Shanghai: Young Men's Christian Association of China, 1935), 48.

101“"John R. Mott to David Z. T. Yui, October 7, 1918" (Chinese Labor Battalion) (YMCA Archives of the USA).

102“"David Z. T. Yui to W. W. Lockwood, March 10th, 1919" (Chinese Labor Battalion) (YMCA Archives of the USA).
} 
into two steps. The first was to offer a place for the laborers to get together for lectures, socials, movies, Bible study class, etc. The second was to arouse the conscience of the Christian church in Shandong so that the church workers could take this opportunity to invite those returned laborers to their churches. ${ }^{103}$ In addition to Shandong, letters from Wuhan also reported the follow-up work. Charles C. Shedd, Y secretary in Hankou, wrote,

An emergency program for returned laborers from France has grown into a work requiring the full and part time of several secretaries. Card records have been prepared for over 300 men, quite a number have found employment through our office, others have come for help in getting their finances adjusted, a few were persuaded to open savings accounts with their money earned overseas, and no end of other services have been rendered these men who are struggling against great odds to readjust themselves to their old life. We will soon open quarters in another section of the city where we will be able more adequately to carry on our employment, educational, religious, and recreational programs for them. ${ }^{104}$

The next step in taking care of these laborers was to launch programs for workers and farmers in the Chinese YMCA. As Mott explained to Yui, "Upon their return they will form a splendid field for rural or industrial Y.M.C.A. work in China." 105 Thus the Industrial Department and programs for farmers of the Chinese YMCA were born. In July 1920, David Yui described their follow-up work for returned laborers as leading them in many centers into rural districts, and the Chinese YMCA was going to study the possibilities of that field and prepare for developing it. ${ }^{106}$ In fact, the rural program and the industrial program were the two new major services of the Chinese YMCA in the 1930s and 1940s. ${ }^{107}$

\section{CONCLUSION}

Scholars have not reached a consensus on the labor service of the Chinese YMCA in World War I. Some scholars downplay the Y's contribution

\footnotetext{
103 "David Z. T. Yui to W. W. Lockwood, March 28, 1919" (Chinese Labor Battalion) (YMCA Archives of the USA).

104"Charles C. Shedd to Dear Friend, August 3, 1920" (Chinese Labor Battalion) (YMCA Archives of the USA).

105“John R. Mott to David Z. T. Yui, October 7, 1918."

106“'David Z. T. Yui to D. W. Lyon, July 7, 1920" (YMCA Archives of the USA).

${ }^{107}$ As for industrial service of the YMCA in China, see Robin Porter, Industrial Reformers in Republican China (Armonk, N.Y.: M. E. Sharpe, 1994), 29-46. A recent book deals with Christian efforts with farmers in Republican China: see Liu Jiafeng, Fuyin yu li: zaihua nongye chuanjiao zhi yanjiu (Gospel and Plow: A Study of Preaching the Gospel to Farmers in China) (Taipei: Cosmic Light, 2006).
} 
because it neither led to the growth of a Christian population in Shandong nor gave any demonstration of civil spirit at the places where laborers returned home. ${ }^{108}$ Some do credit the Y service for bringing comfort to the laborers and cultivating Chinese youth through their participation. ${ }^{109}$ While it is unwise to assess the impact on those 175,000 Chinese laborers, it will be feasible, from the point of view of Chinese church history, to give an evaluation of the Chinese YMCA service to the Chinese laborers in France, which was extraordinarily important and meaningful.

First, this was the first time that Chinese Christians went abroad in large scale to answer the call of an international Christian movement. In the past, China was a mission field that was only a receiver of the Gospel together with missionary aid, charity, and service. Chinese seldom played a meaningful role in the missionary enterprise and thus did not earn much respect from missionary circles. However, the participation of the Chinese Christians in this Y project demonstrated the spiritual maturity of the Chinese Christians. From another perspective, if Chinese Christians, or the Chinese YMCA, did not actively join the service to the Chinese laborers, they not only would have been looked down on by missionaries but they also could not have reached their people in such a meaningful way.

Second, this was the first time that Chinese Christians worked together with foreign missionaries. In the nineteenth century, Chinese Christians could only serve as missionary assistants in Christian societies. In most cases, the Chinese Christians simply accepted orders from the missionaries. However, during World War I their participation in the Y service in France earned praise from all the missionaries. They were taken as equal partners and were deeply valued for their performance. This was especially significant because even the American secretaries and British secretaries could not share in the YMCA project in France in a fully cooperative spirit.

Third, although the YMCA was an organization that placed strong emphasis on noninvolvement in politics, the Chinese Christians who participated in this project were motivated by patriotism and love for their countrymen. They cared about national pride and would not let the performance of the Chinese laborers bring any humiliation to China. This should occupy special attention because it happened even before the May Fourth movement. Chinese Christians demonstrated their love toward China and their caring for countrymen even across national borders, not as a "denationalized" group, which is how they were portrayed by anti-Christians in the 1920s.

\footnotetext{
${ }^{108}$ For this kind of opinion, see Blick, "The Chinese Labor Corps in World War I," and Griffin, "The Use of Chinese Labor by the British Army, 1916-1920."

${ }^{109}$ For this positive opinion, see Chen, "Jidujiao Qingnianhui yu Ouzhan huagong," and Gewurtz, "For God or for King."
} 
Finally, the Chinese YMCA members' work among the labor service was just one contextualization of their service in China. They were not limited to the spiritual, moral, intellectual, and recreational aspects of the youth. They were able to develop new programs that were relevant to the changing times. After the service to laborers in France, the Chinese YMCA created programs for industrial laborers and also for farmers, showing its versatility in serving China. 